\title{
Effect of monensin on the invasiveness and multiplication of Legionella pneumophila
}

\author{
P. GOLdONI, M. CASTELLANI PASTORIS*, L. CATTANI, C. PELUSO $\dagger$, L. SINIBALDI and N. ORSI \\ Istituto di Microbiologia, Università "La Sapienza", * Istituto Superiore di Sanità, †/stituto di /stologia e Embriologia \\ generale, Università "La Sapienza", 00185 Rome, Italy
}

\begin{abstract}
Summary. The polyether antibiotic monensin exhibited bacteriostatic activity against a clinical isolate of Legionella pneumophila in vitro. Experiments designed to test the effect of the compound on the invasiveness and multiplication of L. pneumophila in HeLa cells showed that, in the presence of the antibiotic, legionellas that penetrated the cells did not multiply. However, monensin did not alter the characteristics of phagosomes that contained ingested legionellas. In the presence of monensin, infected cells exhibited extensive vacuolation and a noticeable reduction in the number of intracellular micro-organisms was evident a few hours after infection.
\end{abstract}

\section{Introduction}

Legionella pneumophila is a facultative intracellular pathogen that replicates within a wide variety of cultured human and animal cells, ${ }^{1-6}$ and soil and fresh water protozoa. ${ }^{7-9}$ In cultured non-lymphoid tumour cells, the penetration of $L$. pneumophila takes place by a process that is best described as induced uptake, ${ }^{6}$ and this is considered to be a virulence-associated property. ${ }^{10}$ After uptake, the avoidance of digestion by lysosomal enzymes is achieved by the prevention of phagosome-lysosome fusion, probably induced by a bacterial cytotoxin. ${ }^{11}$ Replication of micro-organisms is accomplished within cytoplasmic vacuoles; transmission electronmicroscopy of intracellular L. pneumophila shows the micro-organisms residing in a ribosome-studded phagosome, a structure unique among intracellular bacteria. ${ }^{12}$ Various inhibitors of eukaryotic metabolism have been used to identify the processes involved in the intracellular replication of L. pneumophila. Among these, two typical lysosomotropic agents, ammonium chloride and chloroquine, showed contrasting results. ${ }^{13}$ Whereas chloroquine prevented almost all intracellular multiplication in $\mathrm{HeLa}$ cells, and caused extensive vacuolation, disruption of calcium metabolism and destruction of monolayers, ammonium chloride had no effect on the multiplication of legionellas. However, Byrd and Horwitz ${ }^{14}$ observed inhibition of multiplication of L. pneumophila in human monocytes by both chloroquine and ammonium chloride.
Monensin is a carboxylic ionophore that affects receptor-mediated endocytosis ${ }^{15}$ by alkalinisation of the content of lysosomes or pre-lysosomal compartments, or both. This effect is a consequence of the insertion of the ionophore into lysosomal membranes. ${ }^{16}$ Because of its lipophilic nature, monensin can insert into cellular membranes to cause a marked slowing of intracellular transport of newly synthesised secretory proteins, proteoglycans and plasma-membrane glycoproteins. The major site of this inhibition is within the Golgi complex, and in this respect the action of monensin is unique. ${ }^{16}$ Monensin also exhibits antibiotic activity by affecting the flux of sodium and potassium ions across the bacterial cell membrane. ${ }^{17,18}$ It is one of several polyether antibiotics used commercially to improve feed efficiency in ruminants. ${ }^{19-23}$ These agents are mainly active against gram-positive micro-organisms. Gram-negative bacteria are generally ionophore-resistant because of the outer membrane which serves as a protective barrier. ${ }^{22}$ Nothing is known about the effect of monensin on Legionella, and the present study was undertaken to examine the activity of the antibiotic in vitro, and on the penetration and multiplication of $L$. pneumophila in HeLa cells.

\section{Materials and methods}

\section{Bacterial strain}

A virulent clinical isolate of $L$. pneumophila serogroup 6, strain Monza 3/1386, ${ }^{24}$ which was subcultured only twice after isolation, was used. The strain was stored as a stock culture at $-70^{\circ} \mathrm{C}$ in skimmed milk, and subcultured once on Buffered 
Charcoal-Yeast Extract Agar with $\alpha$-ketoglutarate $0 \cdot 1 \%$ (BCYE- $\alpha$-agar; Oxoid) ${ }^{25}$ before use.

\section{Cells}

HeLa S3 cells were grown at $37^{\circ} \mathrm{C}$ in Eagle's Minimal Essential Medium (MEM) (Flow Laboratories) containing $\mathrm{NaHCO}_{3} 1.2 \mathrm{~g} / \mathrm{L}$, fetal calf serum (Flow Laboratories) $10 \%$ and $2 \mathrm{~mm}$ glutamine. The same medium containing only fetal calf serum $2 \%$ was used to maintain the cells.

\section{Antibacterial activity of monensin}

Monensin (Sigma) was dissolved in ethanol to achieve a concentration of $1 \mathrm{~mm}$ and stored at $-20^{\circ} \mathrm{C}$.

The minimal inhibitory concentration (MIC) was determined by preparing serial two-fold dilutions of monensin covering the range $50-0.2 \mu \mathrm{M}$ in Yeast Extract Broth (Difco) supplemented with Legionella growth supplement (Oxoid). A standardised L. pneumophila suspension was added to each dilution to obtain a final concentration of $c .10^{5} \mathrm{cfu} / \mathrm{ml}$. After incubation for 48 and $72 \mathrm{~h}$ at $37^{\circ} \mathrm{C}$ in $\mathrm{CO}_{2} 2.5 \%$ in air, tubes were examined for bacterial growth. The lowest concentration of monensin that inhibited visible growth was taken as the MIC. Dilutions without visible growth were plated on BCYE- $\alpha$-agar to determine the minimal bactericidal concentration (MBC).

\section{Cell toxicity test}

To determine the cytotoxic effect, HeLa cells $\left(4 \times 10^{5}\right.$ cells $/ \mathrm{ml}$ ) were seeded in growth medium in 96-well plates $(0.1 \mathrm{ml} /$ well) and incubated with various concentrations of monensin in Eagle's MEM for $1 \mathrm{~h}$ at $37^{\circ} \mathrm{C}$ in a moist air atmosphere containing $\mathrm{CO}_{2} 5 \%$. After a further incubation at $37^{\circ} \mathrm{C}$ for $48 \mathrm{~h}$ in drug-free medium, cells were inspected to detect changes in morphology such as swelling, granularity, rounding or floating. The viability of the cells was determined by neutral red uptake after incubation for $48 \mathrm{~h}$.

\section{Ingestion assay}

A modification of the techniques described by Finlay and Falkow ${ }^{26}$ and Harley and Drasar ${ }^{13}$ was used. For the assay, HeLa cells were suspended in antibiotic-free complete Eagle's MEM, plated in 24well culture dishes (Corning, NY, USA) at $2.2 \times 10^{5}$ cells/well and maintained at $37^{\circ} \mathrm{C}$ in a moist air atmosphere containing $\mathrm{CO}_{2} 2.5 \%$. After incubation for $24 \mathrm{~h}$, cell monolayers were washed twice with antibiotic-free complete Eagle's MEM and $0.25 \mathrm{ml}$ of a bacterial suspension in the same medium $(4 \times$ $10^{3} \mathrm{cfu} / \mathrm{ml}$ ) were added to the cells. After centrifugation for $1 \mathrm{~h}$ at $4000 \mathrm{~g}$, the plates were incubated for $1 \mathrm{~h}$ at $37^{\circ} \mathrm{C}$. The cells were then washed five times with
Eagle's MEM supplemented with gentamicin $50 \mu \mathrm{g} /$ $\mathrm{ml}$ and left in the same medium for $1 \mathrm{~h}$ at $37^{\circ} \mathrm{C}$ to kill non-internalised bacteria. Cells were then washed twice with antibiotic-free complete Eagle's MEM and disrupted by addition of sterile double-distilled water $(0.2 \mathrm{ml} /$ well $)$. The number of viable bacteria in the lysate was counted as described below.

\section{Effect of monensin}

Monensin was tested at concentration of 12.5 and $25 \mu \mathrm{M}$. The compound was added to the cells at various times, from $1 \mathrm{~h}$ before infection to $6 \mathrm{~h}$ after the addition of bacteria to the HeLa cells. In control experiments, the infected cells were exposed to concentrations of ethanol equivalent to those present in the dilutions of monensin. In some experiments, monensin was removed from the monolayers immediately before the infection. In others, monensin was either added to the cells with the inoculum and removed by washing after the infection or added to the maintenance medium at different times after the infection and kept in contact with the cells for $48 \mathrm{~h}$. In these experiments appropriate controls were included in which noninfected cells were maintained in the presence of monensin for $48 \mathrm{~h}$.

\section{Bacterial counts}

The numbers (cfu) of viable legionellas in the inoculum and in the cell lysates were assessed by plating the samples on BCYE- $\alpha$ agar and counting the number of colonies developing after incubation for $72 \mathrm{~h}$ at $37^{\circ} \mathrm{C}$ in a moist air atmosphere containing $\mathrm{CO}_{2}$ $2 \cdot 5 \%$.

\section{Electronmicroscopy}

HeLa cells were washed twice and then fixed for $60 \mathrm{~min}$ at $4^{\circ} \mathrm{C}$ with glutaraldehyde (Electron Microscopy Science, Fort Washington, PA, USA) $2.5 \%$ in $0 \cdot 1 \mathrm{M}$ sodium cacodylate buffer (BDH Limited, Poole), $\mathrm{pH}$ 7.3. Glutaraldehyde was then removed, and the cell monolayers were washed five times with cacodylate buffer. Cells were fixed for $45 \mathrm{~min}$ at $4^{\circ} \mathrm{C}$ in osmium tetroxide (Agar Scientific Ltd, Cambridge) $1 \%$ in zetterquist.

Monolayers were dehydrated in graded ethanol solutions (from $70 \%$ to $100 \%$ ) and removed from the wells by overnight agitation at $18^{\circ}-20^{\circ} \mathrm{C}$ with propylene oxide (Fluka Buchs, Switzerland). Samples were embedded in Epon 812 (Fluka Buchs), and ultrathin sections were mounted on formvar-coated copper grids. The sections were stained with a saturated solution of uranyl acetate (Fluka Buchs) in ethanol $50 \%$ for $3 \mathrm{~min}$, followed by lead hydroxide (ICN Costa Mesa, CA, USA) for $10 \mathrm{~min}$. Electronmicrographs were taken with a Hitachi H-7000 electronmicroscope. 


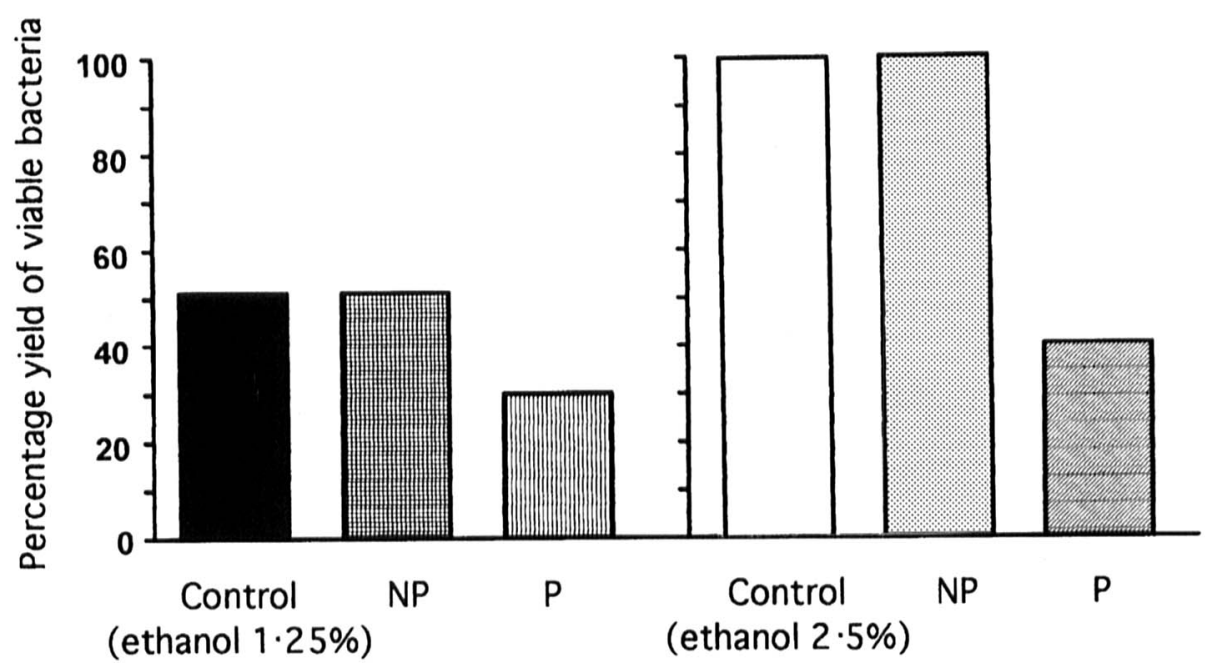

Fig. 1. Effect of monensin on invasiveness of $L$. pneumophila (expressed as percentage yield of viable bacteria relative to a monensin-free control with ethanol $2.5 \%$ ): $\mathbf{\square}$, control with ethanol $1.25 \%$; 橉, monensin $12.5 \mu \mathrm{M}$ added with the bacterial inoculum (NP); 血, cells preincubated with monensin $12.5 \mu \mathrm{M}$ before infection (P); $\square$, control with ethanol $2.5 \%$; , monensin $25 \mu \mathrm{M}$ added with the bacterial inoculum (NP); 罡, cells pre-incubated with monensin $25 \mu \mathrm{M}$ before infection (P).

\section{Results}

\section{Susceptibility test}

MICs of monensin for the virulent strain of $L$. pneumophila tested were 0.78 and $1.56 \mu \mathrm{M}$ after 48 and $72 \mathrm{~h}$, respectively. The MBCs were substantially greater than the MICs, with 5-10\% survival even at $50 \mu \mathrm{m}$ of the drug. Higher concentrations of monensin were cytotoxic.

\section{Effect of monensin on invasiveness of L. pneumophila in HeLa cells}

Pre-incubation of cells with monensin caused a decrease in the number of legionellas entering the cells; the difference was more evident when the monensin was used at a concentration of $25 \mu \mathrm{M}$ (fig. 1). The effect was compared to the appropriate controls in which cells were added with an equivalent amount of ethanol. Ethanol alone at a concentration of $2.5 \%$ caused a higher penetration rate of legionellas into cells, probably due to a perturbation of the cell membrane.

\section{Multiplication of L. pneumophila in HeLa cells in the presence of monensin}

The presence of ethanol in the culture medium allowed the micro-organisms to multiply without affecting bacterial growth. When monensin was added at the time of the infection and removed with the inoculum after $2 \mathrm{~h}$, the growth rate was the same as the controls (fig. 2), indicating that the continued presence of the drug was required to inhibit multiplication of $L$. pneumophila. Addition of monensin to the cells either at the time of the infection or 3 and $6 \mathrm{~h}$ post-infection caused a marked decrease in the number of legionellas as measured by the viable count of bacteria.

Control experiments in parabiotic chambers con-

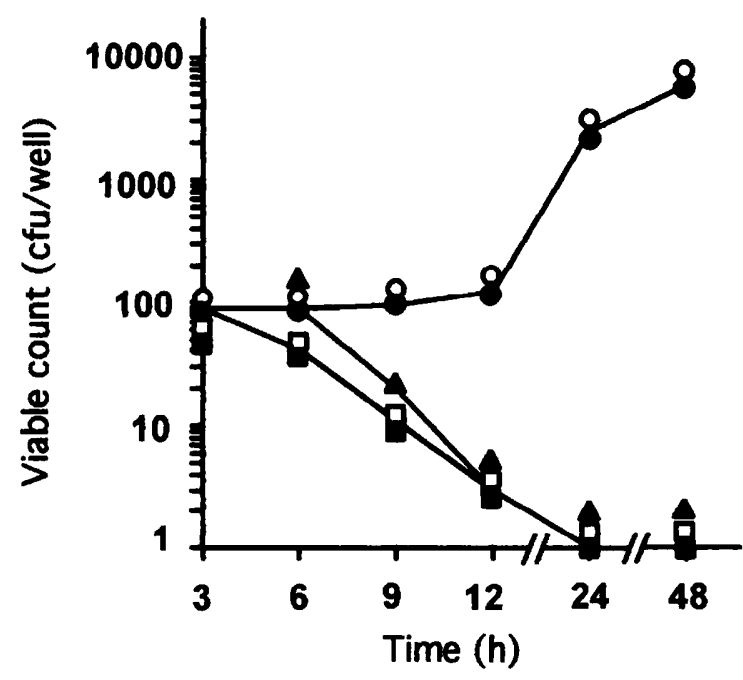

Fig. 2. Multiplication of L. pneumophila in the presence of monensin (counts expressed as number of viable legionellas in the cell lysate of a single well): $O$ antibiotic-free control; $\bigcirc$ monensin $25 \mu \mathrm{M}$ added with the inoculum and removed with the bacteria after $2 \mathrm{~h} ; \square$ monensin $25 \mu \mathrm{M}$ added $3 \mathrm{~h}$ after infection; $\Delta$ monensin $25 \mu \mathrm{M}$ added $6 \mathrm{~h}$ after infection; monensin $25 \mu \mathrm{M}$ added with the inoculum and maintained throughout the experiment ( $48 \mathrm{~h}$ ).

firmed the inability of L. pneumophila to multiply in conditioned medium in the presence of cells separated by a $0.45 \mu \mathrm{m}$ filter or in MEM alone ${ }^{1,5}$ (data not shown).

\section{Electronmicroscopy}

Electronmicroscopy of HeLa cells treated with monensin, or with ethanol at the concentrations used to dilute monensin, showed the complete integrity of cells and the absence of any morphological alteration.

During the first hours of infection, HeLa cells showed vacuoles containing the micro-organisms (figs. 3a and $\mathrm{b}$ ) which multiplied within the vacuoles (fig. 3c). Later, before lysis of the cell, the cytoplasm appeared to be completely altered with several microorganisms in each cell (fig. 3d). 

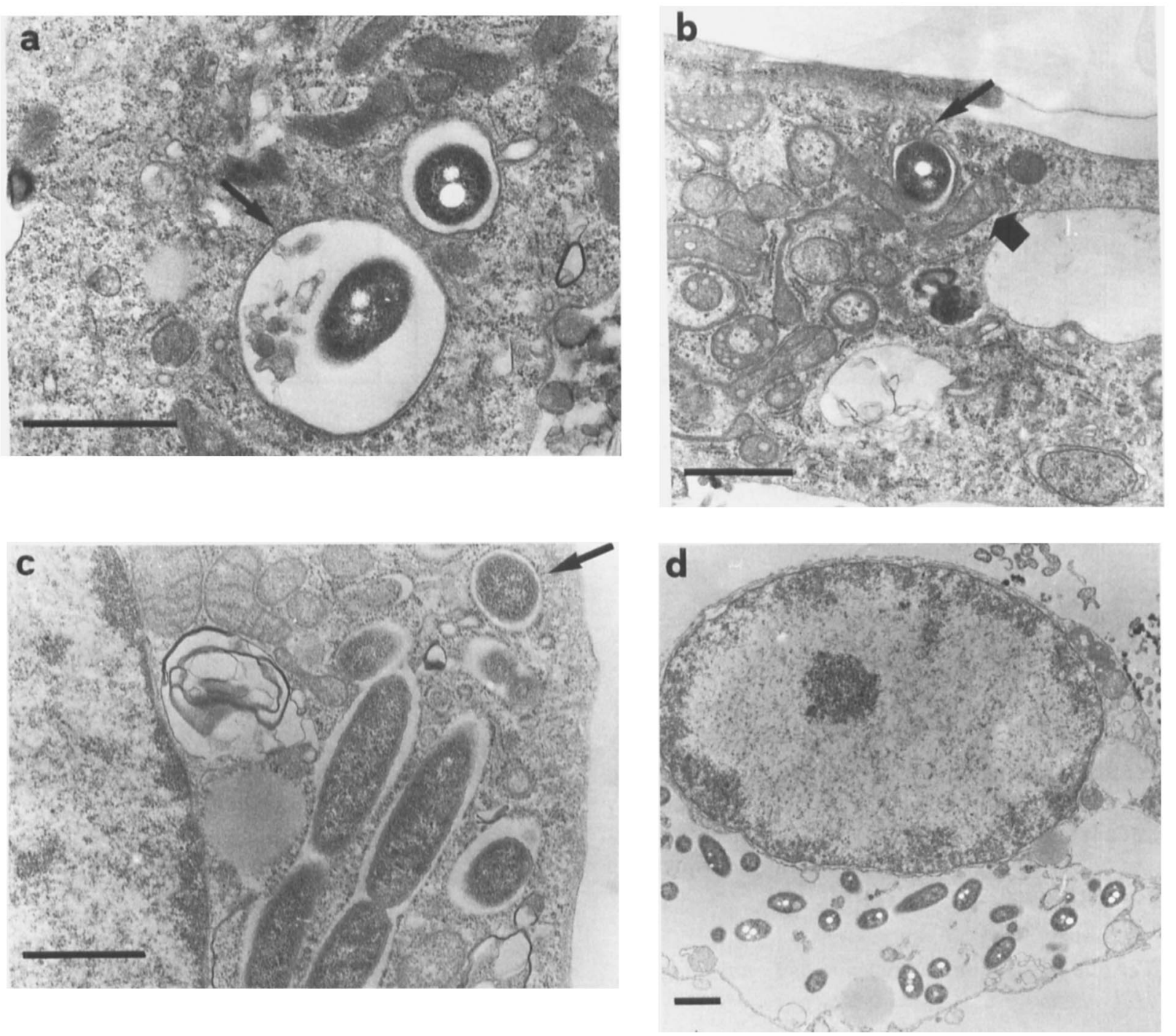

Fig. 3. Intracellular multiplication of $L$. pneumophila in HeLa cells: a, L. pneumophila-containing vacuoles lined with ribosomes (arrow); b, mitochondria closely apposed to the vacuolar membrane (large arrow) - smooth vesicles are apparently fusing with or budding off from the vacuolar membrane (thin arrow); c, replication within vacuoles surrounded by ribosomes (arrow); d, late stage of intracellular development-organisms occupy the entire cell cytoplasmic space. a, b, $3 \mathrm{~h}, \mathbf{c}, 24 \mathrm{~h}, \mathbf{d}, 48 \mathrm{~h}$ after infection. Bars, $1 \mu \mathrm{m}$.

In the presence of monensin, the cycle of multiplication of legionellas in HeLa cells was dramatically interrupted. Intracellular micro-organisms were observed only on rare occasions and visible legionellas were mainly outside the extensively vacuolated cells (figs. 4a, b, c and d).

\section{Discussion}

Although the activity of monensin is exerted mainly on gram-positive and anaerobic bacteria, the clinical isolate of L. pneumophila tested in the present study appeared to be as susceptible as these other microorganisms. ${ }^{23,27}$ In keeping with the results obtained by Nagaraja and Taylor ${ }^{28}$ with other carboxylic ionophores, monensin was found to behave as a bacteriostatic compound within the range of concentrations used, as it was impossible to determine an $M B C$ value. However, concentrations equal to or greater than the MIC caused a fall in the counts of L. pneumophila compared to controls.
L. pneumophila enters human mononuclear phagocytes by a process called "coiling phagocytosis", ${ }^{29}$ and multiplies within an anomalous membrane-bound vacuole studded with ribosomes. Vacuoles usually contain one bacterium, and only occasionally two. Often it is possible to observe smooth vesicles and mitochondria in close proximity to these structures. ${ }^{30}$ Vacuoles containing L. pneumophila do not fuse with lysosomes. ${ }^{31}$

A similar interaction between L. pneumophila and host cell macrophages has also been observed with differentiated HL-60 cells, a promyelocyte cell line readily maintainable in culture, although the receptors mediating adherence were different..$^{32}$

Various studies have described the growth of $L$. pneumophila in several types of non-professional phagocytic cell (MRC-5, HeLa, Hep-2, McCoy, Vero, L929) in tissue culture. ${ }^{4-6,10,33}$ Infected cell monolayers allowed bacterial multiplication and showed cytopathic changes varying from lysis of the cells to a more chronic type of infection. Intracellular replication was 

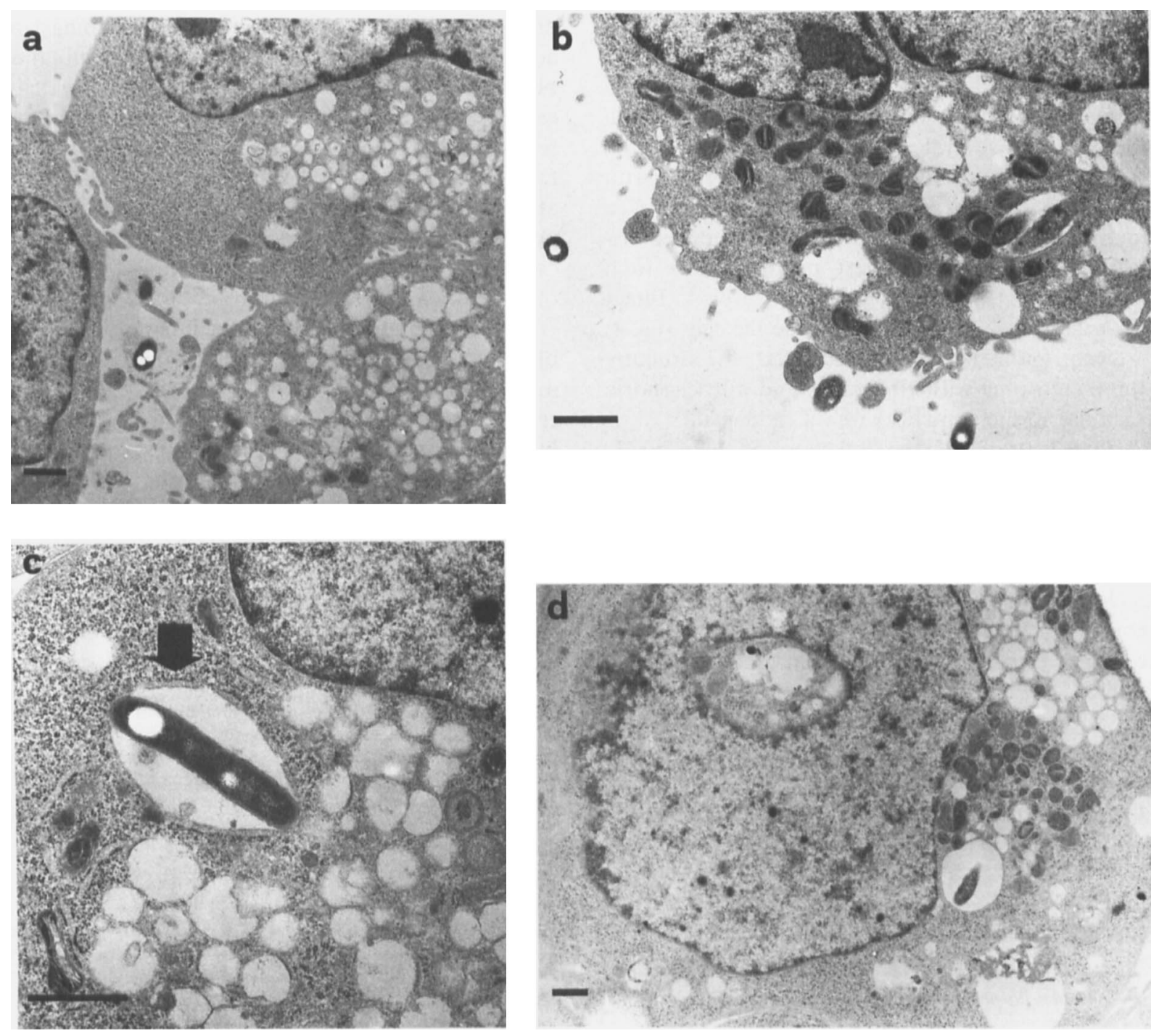

Fig. 4. Infected HeLa cell monolayers in the presence of monensin: a, b, cells showing extensive vacuolation and extracellular bacteria; c, organism inside a vacuole studded with ribosomes (arrow)-note the extensive vacuolation; d, mitochondria in proximity to the $L$. pneumophila vacuole. $\mathbf{a}, 3 \mathrm{~h}, \mathbf{b}, 4 \mathrm{~h}, \mathbf{c}, 6 \mathrm{~h}, \mathbf{d}, 10 \mathrm{~h}$ after infection. Bars, $1 \mu \mathrm{m}$.

similar for each cell type with the presence of vacuoles lined with cell ribosomes and adjacent to mitochondria and other cell structures. ${ }^{6}$ However, engulfment of $L$. pneumophila by non-professional phagocytes is different, since coiling phagocytosis is not observed. Expression of the uptake into HeLa cells induced by L. pneumophila appears to be a virulence-associated property as it has been reported that virulent strains entered cultured HeLa cells 1000 times more efficiently than isogenic avirulent isolates. ${ }^{10}$ The present studies were performed in HeLa cells with a virulent clinical isolate of $L$. pneumophila. This strain entered $\mathrm{HeLa}$ cells more efficiently than the Philadelphia 1 reference strain (data not shown). In order to improve the attachment efficiency, which is low, even with virulent strains, ${ }^{6}$ the bacterial inoculum was centrifuged on to cell monolayers.

The results obtained demonstrate that L. pneumophila failed to replicate in HeLa cells in the presence of monensin. Furthermore, the number of legionellas decreased during the incubation period by a factor of
100 or more compared to controls that grew exponentially. Monensin also caused a fall in viable count when it was added 3 and $6 \mathrm{~h}$ after the infection, confirming that the antibacterial effect continued after bacterial division had started. In these experiments the inoculum of legionellas was relatively low, in order to emphasise possible effects of the antibiotic. Preincubation of cells with monensin did not modify the multiplication of internalised legionellas (data not shown). However, in experiments performed without pre-incubation with the drug, monensin, which penetrates cells within 1-2 min of addition, ${ }^{15}$ produced a bactericidal effect on internalised bacteria. The disappearance of legionellas was confirmed by transmission electronmicroscopy $3,4,6$ and $10 \mathrm{~h}$ after infection of tissue culture cells.

In the absence of monensin, L. pneumophila multiplied 100-fold (fig. 2). Transmission electronmicroscopy performed at 3,24 and $48 \mathrm{~h}$ after infection revealed actively multiplying intracytoplasmic organisms in membrane-bound vacuoles lined with ribo- 
somes. In the late stages of infection dilated vacuoles contained many legionellas (fig. 3).

In contrast, electronmicrographs of infected $\mathrm{HeLa}$ cells treated with monensin showed very few bacteria inside cells with several vacuoles. The presence of an intensive vacuolation in eukaryotic cells treated with monensin has been explained as the result of a dramatic dilatation of the normally compressed cisternae of the Golgi complex, probably due to a perturbation of the intracellular ion levels. ${ }^{16}$ Intact micro-organisms were present outside the cells (fig. 4) but, when legionellas were intracellular, the structure of the phagosome with ribosomes and mitochondria was similar to the controls without monensin.

Certain features of the infection of cells by $L$. pneumophila are also seen with other intracellular pathogens such as Toxoplasma gondii and Chlamydia spp. ${ }^{34,35}$ The vacuole structure containing the microorganisms and the disposition of cytoplasmic organelles close to the vacuole itself are also seen with these organisms. ${ }^{30}$ In addition, like legionellas, these intracellular parasites inhibit phagosome-lysosome fusion. ${ }^{34,35}$

The mechanism by which monensin exerts a bactericidal effect on intracytoplasmic legionellas is not clear. The common property shared by this drug with all the lysosomotropic agents is that of increasing the $\mathrm{pH}$ of acidic compartments such as phagosomes. This

\section{References}

1. Horwitz MA, Silverstein SC. Legionnaires' disease bacterium (Legionella pneumophila) multiplies intracellularly in human monocytes. J Clin Invest 1980; 66: 441-450.

2. Kishimoto RA, White JD, Shirey FG et al. In vitro response of guinea pig peritoneal macrophages to Legionella pneumophila. Infect Immun 1981; 31: 1209-1213.

3. Jacobs RF, Locksley RM, Wilson CB, Haas JE, Klebanoff SJ. Interaction of primate alveolar macrophages and Legionella pneumophila. J Clin Invest 1984; 73: 1515-1523.

4. Wong MC, Ewing EP, Callaway CS, Peacock WL. Intracellular multiplication of Legionella pneumophila in cultured human embryonic lung fibroblasts. Infect Immun 1980; 28: 1014 1018.

5. Daisy JA, Benson CE, McKitrick J, Friedman HM. Intracellular replication of Legionella pneumophila. J Infect Dis $1981 ; 143: 460-464$.

6. Oldham LJ, Rodgers FG. Adhesion, penetration and intracellular replication of Legionella pneumophila: an in vitro model of pathogenesis. J Gen Microbiol 1985; 131: 697-706.

7. Rowbotham TJ. Preliminary report on the pathogenicity of Legionella pneumophila for freshwater and soil amoebae. J Clin Pathol 1980; 33: 1179-1183.

8. Fields BS, Shotts EB, Feeley JC, Gorman GW, Martin WT. Proliferation of Legionella pneumophila as an intracellular parasite of the ciliated protozoan Tetrahymena pyriformis. Appl Environ Microbiol 1984; 47: 467-471.

9. Barbaree JM, Fields BS, Feeley JC, Gorman GW, Martin WT. Isolation of protozoa from water associated with a legionellosis outbreak and demonstration of intracellular multiplication of Legionella pneumophila. Appl Environ Microbiol 1986; 51 : $422-424$.

10. Dreyfus LA. Virulence associated ingestion of Legionella pneumophila by HeLa cells. Microb Pathog 1987; 3: 45-52.

11. Friedman RL, Lochner JE, Bigley RH, Iglewski BH. The effects of Legionella pneumophila toxin on oxidative processes and bacterial killing of human polymorphonuclear leukocytes. $J$ Infect Dis 1982; 146: 328-334. prevents some micro-organisms from escaping from acidic phagosomes $;{ }^{36}$ however, this mechanism cannot be effective in the case of $L$. pneumophila which is capable of multiplying in the phagosome consequent to the inhibition of phagosome-lysosome fusion. The fall in viable count of intracellular legionellas found after exposure to monensin is unlikely to be due to the penetration of gentamicin into cells, despite the high concentrations used $(50 \mathrm{mg} / \mathrm{l})$, because it was not observed in appropriate controls.

It has been reported that intracellular multiplication of $L$. pneumophila is dependent upon the availability of iron in monocytes ${ }^{37}$ and HL-60 cells. $^{32}$ Lysosomotrophic bases interfere with normal iron metabolism by raising endocytic and lysosomal $\mathrm{pH} ;{ }^{38}$ in fact chloroquine and ammonium chloride inhibit intracellular multiplication of $L$. pneumophila in human monocytes. ${ }^{14}$ Since monensin is a carboxylic ionophore which shares with weak bases the ability to increase the $\mathrm{pH}$ of cell compartments, it is possible that the inhibition of multiplication of legionellas in $\mathrm{HeLa}$ cells is also related to altered iron metabolism.

We are grateful to Professor M. Stefanini of the Institute of Histology and general Embryology for critical reading of the manuscript and to Ms Stefania De Grossi of the same Institute for excellent technical assistance in the preparation of electronmicroscopy specimens and for printing the photographs. This work was supported by a grant of MURST (Ministero della Università e della Ricerca Scientifica e Tecnologica).

12. Harley VS, Drasar BS, Forrest B, Krahn B, Tovey G. Invasion strategies and intracellular growth of bacterial pathogens. Biochem Soc Trans 1989; 17: 1118.

13. Harley VS, Drasar BS. Interaction of Legionella pneumophila with tissue culture cells. Biochem Soc Trans 1989; 17: $1118-1119$.

14. Byrd TF, Horwitz MA. Chloroquine inhibits the intracellular multiplication of Legionella pneumophila by limiting the availability of iron. A potential new mechanism for the therapeutic effect of choroquine against intracellular pathogens. J Clin Invest $1991 ; 88$ : 351-357.

15. Maxfield FR. Weak bases and ionophores rapidly and reversibly raise the $\mathrm{pH}$ of endocytic vesicles in cultured mouse fibroblasts. J Cell Biol 1982; 95: 676-681.

16. Tartakoff AM. Perturbation of vesicular traffic with the carboxylic ionophore monensin. Cell 1983; 32: 1026-1028.

17. Russell JB. A proposed mechanism of monensin action in inhibiting ruminal bacterial growth: effects on ion flux and protonmotive force. J Anim Sci 1987; 64: 1519-1525.

18. Chow JM, Russell JB. Effect of ionophores and pH on growth of Streptococcus bovis in batch and continuous culture. Appl Environ Microbiol 1990; 56: 1588-1593.

19. Rumsey TS. Monensin in cattle: introduction. J Anim Sci 1984; 58: 1461-1464.

20. Schelling GT. Monensin mode of action in the rumen. $J$ Anim Sci 1984; 58: 1518-1527.

21. Goodrich RD, Garrett JE, Gast DR, Kirick MA, Larson DA, Meiske JC. Influence of monensin on the performance of cattle. J Anim Sci 1984; 58: 1484-1498.

22. Russell JB, Strobel HJ. Effect of ionophores on ruminal fermentation. Appl Environ Microbiol 1989; 55: 1-6.

23. Borders D. Antibiotics (survey). In: Howe-Grant M (ed) Chemotherapeutics and disease control. New York, John Wiley and Sons. 1993: 107-118.

24. Viganò EF, Giltri G, Cappellini A, Brenna A, Castellani Pastoris M. Polmonite nosocomiale infausta da Legionella pneumophila sierogruppo 6. In: Microbiologia delle infezioni ospedaliere. XVIII Congresso Nazionale Associazione Microbiologi Clinici Italiani. Rome, 8-11 November 1989: 121. 
25. Edelstein PH. Improved semiselective medium for isolation of Legionella pneumophila from contaminated clinical and environmental specimens. J Clin Microbiol 1981; 14: 298-303.

26. Finlay BB, Falkow S. Comparison of the invasion strategies used by Salmonella cholerae-suis, Shigella flexneri and Yersinia enterocolitica to enter cultured animal cells: endosome acidification is not required for bacterial invasion or intracellular replication. Biochimie 1988; 70: 1089-1099.

27. Dawson KA, Boling JA. Effects of potassium ion concentrations on the antimicrobial activities of ionophores against ruminal anaerobes. Appl Environ Microbiol 1987; 53: $2363-2367$.

28. Nagaraja TG, Taylor MB. Susceptibility and resistance of ruminal bacteria to antimicrobial feed additives. Appl Environ Microbiol 1987; 53: 1620-1625.

29. Horwitz MA. Phagocytosis of the Legionnaires' disease bacterium (Legionella pneumophila) occurs by a novel mechanism: engulfment within a pseudopod coil. Cell 1984; 36: 27-33.

30. Horwitz MA. Formation of a novel phagosome by the Legionnaires' disease bacterium (Legionella pneumophila) in human monocytes. $J$ Exp Med 1983; 158: 1319-1331.

31. Horwitz MA. The legionnaires' disease bacterium (Legionella pneumophila) inhibits phagosome-lysosome fusion in human monocytes. $J$ Exp Med 1983; 158: 2108-2126.
32. Marra A, Horwitz MA, Shuman HA. The HL-60 model for the interaction of human macrophages with the Legionnaires' disease bacterium. J Immunol 1990; 144: 2738-2744.

33. Fernandez RC, Lee SHS, Haldane D, Sumarah R, Rozee KR. Plaque assay for virulent Legionella pneumophila. $J$ Clin Microbiol 1989; 27: 1961-1964.

34. Jones TC, Hirsch JG. The interaction between Toxoplasma gondii and mammalian cells. II. The absence of lysosomal fusion with phagocytic vacuoles containing living parasites. J Exp Med 1972; 136: 1173-1194.

35. Friis RR. Interaction of $\mathrm{L}$ cells and Chlamydia psittaci: entry of the parasite and host responses to its development. $J$ Bacteriol 1972; 110: 706-721.

36. Ley V, Robbins ES, Nussenzweig V, Andrews NW. The exit of Trypanosoma cruzi from the phagosome is inhibited by raising the $\mathrm{pH}$ of acidic compartments. J Exp Med 1990; 171: 401-413.

37. Byrd TF, Horwitz MA. Interferon gamma-activated human monocytes downregulate transferrin receptors and inhibit the intracellular multiplication of Legionella pneumophila by limiting the availability of iron. $J$ Clin Invest $1989 ; \mathbf{8 3}$ : $1457-1465$.

38. Armstrong NJ, Morgan EH. The effect of lysosomotrophic bases and inhibitors of transglutaminase on iron uptake by immature erythroid cells. Biochim Biophys Acta 1983; 762: 175-186. 